\title{
Evaluating of Digital Platforms Related Online Learning During Covid-19 Pandemic: Students' Satisfaction View
}

\author{
Sudung Nainggolan ${ }^{1}$ \\ DOI: $10.35445 /$ alishlah.v13i2.912
}

Article Info

Keywords:

Covid-19 Pandemic;

Digital Platforms;

Online Learning;

Satisfaction

Kata kunci:

Pandemi Covid-19;

Aplikasi Digital;

Pembelajaran Daring;

Kepuasaan

\begin{abstract}
Various technology applications have been used in the teaching and learning process as a medium in the Covid-19 pandemic era to make the learning process easier. This study aims to determine the results of the evaluation of digital platforms for online learning systems that have been used during the covid-19 pandemic. Digital platforms a multimedia technology that facilitates online learning activities easily, especially during the current pandemic through the internet network. The research method used a qualitative descriptive crosssectional. The subjects of the study were postgraduate students in Institute Injil Indonesia that were 90 students. The sample is taken using a simple random sample. Data were collected using questionnaires and interviews. The data were analyzed using data reduction, data presentation, and conclusion drawing. The results showed that students had a high level of satisfaction with Zoom as a digital platform in video conferencing and other digital platform applications that were considered satisfying, namely YouTube and Whatsapp. However, educators and some lecturers also like to use email for task collection activities during online learning activities during the covid-19 pandemic. The results of this study have implications for the development of digital applications for the management of online learning activities in the provision of paid video conferencing facilities for Institut Injil Indonesia.
\end{abstract}

\begin{abstract}
Abstrak
Berbagai aplikasi teknologi telah dimanfaatkan dalam proses pengajaran dan pembelajaran sebagai media di era pandemic Covid-19 agar proses belajar menjadi lebih mudah. Penelitian ini bertujuan untuk mengetahui hasil evalulasi digital platform untuk sistem belajar online yang telah digunakan selama masa pandemic covid-19. Digital platform sebagai salah satu multimedia teknologi yang memfasilitasi kegiatan belajar online dengan mudah apalagi di masa pandemic sekarang melalui jaringan internet. Metode penelitian menggunakan kualitatif deskriptif cross sectional. Subyek penelitian adalah mahasiswa pascasarjana Institut Injil Indonesia yang berjumlah 90 mahasiswa. Sampel diambil dengan menggunakan sampel acak sederhana. Data dikumpulkan menggunakan kuesioner dan wawancara. Data dianalisis menggunakan reduksi data, penyajian data dan pengambilan simpulan. Hasil penelitian menunjukkan bahwa mahasiswa mempunyai tingkat kepuasaan tinggi pada zoom sebagai digital platform dalam bentuk video conference dan aplikasi digital platform lainnya yang dianggap memberikan kepuasaan adalah YouTube dan Whatsapp. Namun, pendidik dan beberapa dosen juga suka menggunakan email untuk kegiatan pengumpulan tugas selama kegiatan belajar online dimasa pandemic
\end{abstract}

${ }^{1}$ Posgraduate Program, Manajemen Pendidikan, Institut Injil Indonesia

Email: sudungn@gmail.com 
covid-19. Hasil penelitian ini berimplikasi pada pengembangan aplikasi digital manajemen kegiatan belajar online dalam penyediaan fasilitas video conference berbayar untuk Institut Injil Indonesia.

\section{INTRODUCTION}

The Covid-19 pandemic that has occurred since December 2020 in China has spread throughout the world. This condition has also affected human life, from the economic sector to education (Hoofman \& Secord, 2021). In providing education, the implementation of teaching and learning is required to change face-to-face learning to online. It means that there is a rapid transition in maintaining the balance of education. To meet the achievement of educational goals during the Covid-19 pandemic, technology has now become one of the best ways to implement education. Under these conditions, every institution or educational institution is required to use digital platforms as a medium in the implementation of online teaching and learning.

Online teaching and internet technology in education should be carried out generally as in classroom learning activities. Of course, the online learning system requires educators' adaptive and collaborative attitudes (Rajhans et al., 2020). Online learning during the COVID-19 pandemic should not be considered an emergency condition that can impact learning outcomes. Online learning activities must have an ecosystem such as face-to-face learning (Patricia Aguilera-Hermida, 2020). So that students can get a learning experience that can provide maximum learning outcomes. This means that online learning activities require a student's self-regulation skills and skills to initiate and maintain social contacts for interactive learning activities (Eberle \& Hobrecht, 2021). Thus, students can have difficulty during online learning and have satisfaction according to student needs.

The results of observations in preliminary research in the even semester of the 2020-2021 academic year through the distribution of learning outcomes questionnaires to students regarding the implementation of online learning for one semester, concluded that there was dissatisfaction with the use of digital platforms as online learning media in the postgraduate program of the Institut Injil Indonesia in Batu Malang. Student learning outcomes have also decreased due to the low quality of the internet network. Poor internet connection is a factor that affects the comfort and success of learning (Alsmadi et al., 2021). This means that online learning activities using digital platforms are not going well. However, the conclusion of the problem from the evaluation of learning outcomes still needs to be studied more deeply from various perspectives. Thus, the online learning process problems found at the Institut Injil Indonesian for master's and doctoral program students are related to digital applications that suit their needs. Therefore, evaluation from a student's perspective is one of the best ways to determine what students want to use digital applications. Moreover, many digital applications have been used and provided by various parties such as the government, universities, and the private sector to implement online learning and teaching during the Covid-19 pandemic.

Therefore, this research must be carried out because 1) online learning systems are currently the best way to carry out educational activities in pandemic covid-19 and the advanced of technology digital, 2) online learning systems can be carried out such as face-to-face learning activities in class, 3) technological advances through various digital platforms or other multimedia has replaced faceto-face communication with online, 4) the variety of free and paid digital platforms makes it easy for educators and students to carry out online learning activities, 5) digital platforms can be accessed through various technological devices or cellular phones.

Thus, this study seeks to evaluate the digital platforms that have been used in online learning activities from the perspective of students. This is based on the assumption that technological progress has become a bridge for increasing knowledge. Many studies have been conducted previously related to digital technology tools or the application of techniques used to improve online teaching and learning quality. In addition, online learning also requires students to be independent 
learners (Wong et al., 2021), although many students are dissatisfied with the experience of the online learning system (Maqableh \& Alia, 2021). A different view was expressed by Zain (2021) that digital transformation improves pedagogy, providing new learning experiences for students as mobile devices used in the learning process can improve collaboration (Heflin et al., 2017). Mobile technology has become popular worldwide with a wide range of users, including students of all educational levels. So, teachers should take advantage of the combination of affordability of mobile and App technology that improves some aspects of learning practice (Domingo \& Garganté, 2016)

Students feel that the use of digital platforms is the primary medium in transferring knowledge to students. In contrast, online learning activities through various digital platforms in postgraduates should facilitate online learning activities in achieving educational goals. The current pandemic situation requires universities to adopt the changes in the learning system that is online learning system (Baber, 2021). University policymakers should consider student psychology in virtual teaching and learning environments (Shah et al., 2021). Universities must prepare all the facilities needed for online learning activities in each study program for the master or doctoral program level. However, the results of observations show that the readiness of these facilities does not meet the standards that can meet the needs of online learning activities, especially digital platforms.

However, this research is oriented towards evaluating the digital platform used at the Institut Injil Indonesia Postgraduate through the level of student satisfaction. This gap provides new value in understanding the education system evaluation process related to teaching and learning management. Student assessment is an important point for evaluating the use of multimedia specifically for digital platforms. The results of this study can be considered for improving the use of multimedia for educators. They can apply the concept of direct online learning through appropriate digital platforms according to their level of education (Tang et al., 2021). The results of the evaluation of the digital platform in the context of student needs are a form of the gap between this research and other studies. Thus, the online learning process remains oriented to the student learning experience, which greatly helps understand the learning context (Warfvinge et al., 2021).

So, the purpose of this study was to obtain evaluation results from the use of digital platforms that have been used by educators in the online learning process at the Institut Injil Indonesia Postgraduate through student satisfaction. Thus this research can be useful for developing a digital platform that is suitable for the postgraduate level of higher education or students' university.

\section{METHODS}

The study was conducted in Institut Injil Indonesia. The subject of the study were postgraduate students in Institut Injil Indonesia that were studying in magister and doctoral program. They are $90(\mathrm{M}=45$ and $\mathrm{F}=45)$. The method used to take the subject of study as a sample is a simple random sample (Taylor et al., 2004). It was selected using a specific number of units drawn from the population investigated, which is treated as an undifferentiated whole. Thus, the study used the descriptive qualitative cross-sectional method. It investigated the phenomenon related to the digital platform used in an online learning system for a pandemic covid-19 period. It refers to students' satisfaction view on implementing a digital platform for an online learning system. The cross-sectional design is used to describe the information in the field but does not manipulate the variables (Allen, 2017). This research is based on facts and characteristics described by students according to their individual needs related to digital platforms for online learning activities.

Participants ( $\mathrm{n}=90$ postgraduate students) will fill the questionnaire about the digital platform in the online learning system. The questionnaire is designed using closed ended-questions. The designed questions relate to the different types of digital platforms that educators have used. The answers provided use a Likert scale model with choices of very satisfied, satisfied, sometimes satisfied, dissatisfied, very dissatisfied. The data is presented in the form of a percentage to determine the level of student satisfaction. Furthermore, the percentage is narrated as the result of 
the analysis. To emphasize questionnaire data, the interview is done for some students and teachers in the university. Thus, the data analysis stage consists of three steps: data reduction, data presentation, and concluding.

\section{FINDINGS AND DISCUSSION}

The result of questionnaire data analysis is presented through the graph below;

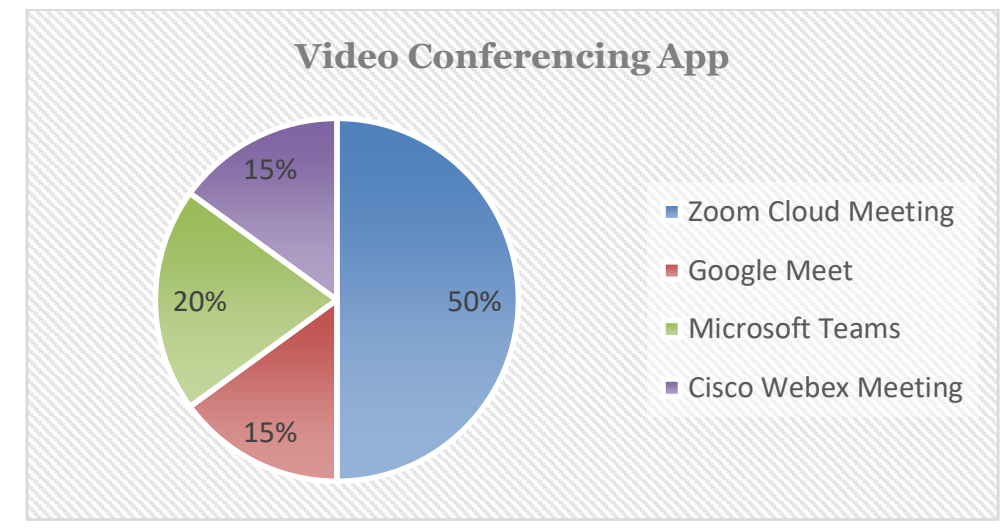

\section{Graph 1. Video Conference App for Online Learning}

Graph 1 described the questionnaire data analysis from students' university views about video conferencing App in online learning. It concludes that students have a high level of satisfaction with using zoom clouds meeting for online learning activities as a digital media technology. This is because the zoom has very good HD quality and can accommodate many students, and can view more than one video at a time in one view. In addition, the zoom display is attractive and has a Virtual Background feature with various themes and makes the background move. Moreover, the weakness of zoom is limited, such as the time quota for unpaid zoom for 40 minutes. However, even this weakness can still be overcome by repeating creating a user id if online learning activities continue.

The graph shows that the level of satisfaction for each video conferencing application is different. While the satisfaction level for Microsoft Teams is 20\%, and Google Meet or Cisco Webex Meetings have a satisfaction of $15 \%$. These findings can have implications for consideration in providing paid zoom cloud meeting services to increase student capacity and provide longer study time. In research by Cuaca Dharma et al. (2017), it is known that the advantages of webinar learning online media, such as Skype and Zoom, are their ability to allow participants to interact in writing and verbally as well as share presentation screens through the sharing display feature. Since one of the most critical factors in online learning is the internet, Zoom is recommended over Skype. So, students have a positive attitude towards using the Zoom application (Vandenberg \& Magnuson, 2021).

The results of student satisfaction also show promising results for other digital platforms besides video conferencing, as shown in the following graph:

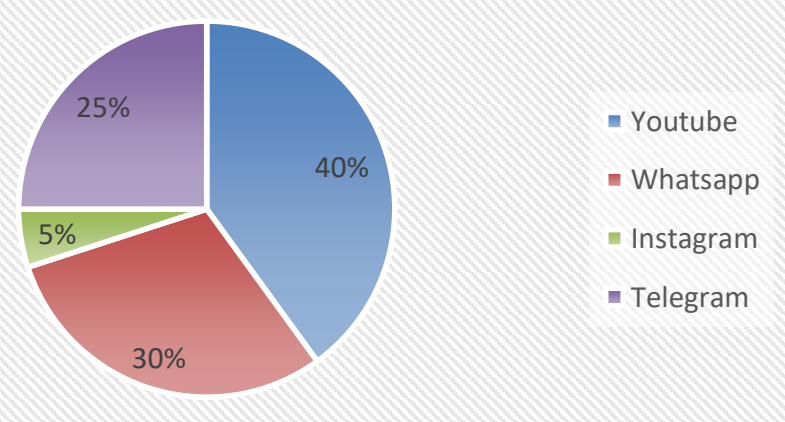

Graph 2. Another Digital Platform (Multimedia Technology) 
Graph 2 described the questionnaire data analysis is taken from some social media that supported the online learning process. Some educators in Institut Injil Indonesia used YouTube, WhatsApp, Instagram, and Telegram in the discussion process when the online learning did not use the video conference. They used media to describe the material. Moreover, social media has become an inseparable part of our lives in recent days (Yildiz, 2020). It concludes that other digital platform applications also have different levels of satisfaction on each platform. Each postgraduate study program gives educators the freedom to use digital platforms as learning media and collecting assignments. From the questionnaire data analysis results, it was stated that assignments and materials could be collected through YouTube and followed by Whatsapp as the medium. However, the interviews with educators revealed that they were more satisfied and liked to use email for collecting assignments. Some students also agree that email is an accessible medium to collect assignments. In addition, students and educators also think that postgraduates should design websites such as learning management systems as online learning facilities. It means that all online learning activities are carried out in one learning management system. Some universities used YouTube as a complementary teaching tool (Moghavvemi et al., 2018)

The finding data implies an understanding that every online learning activity during the COVID-19 pandemic must provide multimedia technology facilities that are by the background conditions of students. The data findings explain that students show their satisfaction and desire for digital platforms for online learning activities. This context is based on students' ability to provide quotas and the existence of an internet network. Currently, these two things are the most critical factors affecting online learning activities. From the interviews with the students, it was found that $50 \%$ of students like online learning, and 50\% of students like face-to-face learning with a direct learning approach, because they can interact more easily without internet network problems or problems. It means that the educator must have innovation and creativity to transform digital technology to create learning meaning (Di Vaio et al., 2021; Bereczki \& Kárpáti, 2021). It can show the performance (Nasiri et al., 2020). The theme of technology acceptance in teacher practice is still a meaningful subject for professional perception and vision (Toto \& Limone, 2021; Instefjord \& Munthe, 2017).

In their study, Vandenberg \& Magnuson (2021) concluded that some college students and faculty prefer a direct learning approach to online platforms in a pandemic situation. However, some students also showed negative attitudes towards online practice because online learning activities lacked interactive communication and skill development. Advances in technology in providing digital platforms as online learning media still have weaknesses and differences in building interactive communication compared to direct communication in the classroom. In this case, online learning facilitated by digital platforms has several categories, namely (i) supervised online learning where full feedback information is always available, (ii) online learning with limited feedback, and (iii) unsupervised online learning where there is no feedback available (H. Hoi et al., 2021). In this perspective, the perceived usefulness of the currently used online learning platforms is an important aspect, especially in the absence of physical classes (Pal \& Vanijja, 2020).

The online learning system can be understood that its application must pay attention to many factors. Every university is ready for digital technology facilities and must pay attention to many aspects of psychology or management systems. The context of students with diverse backgrounds, internet networks in each student area, readiness and skills of educators in classroom management, as well as higher education management in building an online teaching and learning system that is integrated with all parties. It means that online learning using digital technology has a complex distraction and reduced focus, psychological problems, and management problems (Maqableh \& Alia, 2021). However, educators should also note that basic digital skills and technology-related teaching skills are more important than digital technology resources (Sailer et al., 2021; Zhao et al., 2021). It means that the various kinds of digital platforms that have been provided may not 
necessarily provide many benefits to online learning outcomes if educators do not maximize every function of the digital platform because they do not have digital skills. Technology has provided a significant change in the interest in using digital technology in universities today (Limani et al., 2019) CONCLUSION

The findings conclude that students have a good level of satisfaction with using digital platform applications during the online learning process during the covid-19 pandemic. This satisfaction is aimed at using Zoom cloud meetings, YouTube, and Whatsapp applications. However, some students and educators gave different opinions from the questionnaire data, namely the use of email as a media for collecting assignments. Universities could make a learning management system an application that facilitates online learning activities. This research is still limited to evaluating digital platforms for online learning at universities that focus on the results of data input from students' satisfaction perspectives. In this case, the evaluation data is taken from the results of the student context. Thus, this research can still be developed on the design of learning management systems in student needs. Research data is taken into consideration to improve the quality of education.

In addition, this research can also be used by educators at other educational institutions or universities related to the suitability of using online applications for online teaching and learning processes. This means that research results can impact educators' understanding of digital applications that can be used for teaching and learning activities at universities during the Covid-19 pandemic era. Moreover, each region has a different background in providing internet networks and students' ability to provide quotas for online learning.

\section{REFERENCES}

Allen, M. (2017). The SAGE Encyclopedia of Communication Research Methods. The SAGE Encyclopedia of Communication Research Methods. https://doi.org/10.4135/9781483381411

Alsmadi, M. K., Al-Marashdeh, I., Alzaqebah, M., Jaradat, G., Alghamdi, F. A., Mustafa A Mohammad, R., Alshabanah, M., Alrajhi, D., Alkhaldi, H., Aldhafferi, N., Alqahtani, A., Badawi, U. A., \& Tayfour, M. (2021). Digitalization of learning in Saudi Arabia during the COVID-19 outbreak: A survey. Informatics in Medicine Unlocked, 25, 100632. https://doi.org/10.1016/J.IMU.2021.100632

Baber, H. (2021). Modelling the acceptance of e-learning during the pandemic of COVID-19-A study of South Korea. The International Journal of Management Education, 19(2), 100503. https://doi.org/10.1016/J.IJME.2021.100503

Bereczki, E. O., \& Kárpáti, A. (2021). Technology-enhanced creativity: A multiple case study of digital technology-integration expert teachers' beliefs and practices. Thinking Skills and Creativity, 39, 100791. https://doi.org/10.1016/j.tsc.2021.100791

Cuaca Dharma, H. R., Asmarani, D., \& Dewi, U. P. (2017). Basic Japanese Grammar and Conversation e-learning through Skype and Zoom Online Application. Procedia Computer Science, 116, 267-273. https://doi.org/10.1016/J.PROCS.2017.10.055

Di Vaio, A., Palladino, R., Pezzi, A., \& Kalisz, D. E. (2021). The role of digital innovation in knowledge management systems: A systematic literature review. Journal of Business Research, 123, 220231. https://doi.org/10.1016/j.jbusres.2020.09.042

Domingo, M. G., \& Garganté, A. B. (2016). Exploring the use of educational technology in primary education: Teachers' perception of mobile technology learning impacts and applications' use in the classroom. Computers in Human Behavior, 56, 21-28. https://doi.org/10.1016/J.CHB.2015.11.023

Eberle, J., \& Hobrecht, J. (2021). The lonely struggle with autonomy: A case study of first-year university students' experiences during emergency online teaching. Computers in Human Behavior, 121, 106804. https://doi.org/10.1016/J.CHB.2021.106804

H. Hoi, S. C., Sahoo, D., Lu, J., \& Zhao, P. (2021). Online learning: A comprehensive survey. Neurocomputing, 459, 249-289. https://doi.org/10.1016/J.NEUCOM.2021.04.112 
Heflin, H., Shewmaker, J., \& Nguyen, J. (2017). Impact of mobile technology on student attitudes, engagement, and learning. Computers \& Education, 107, 91-99. https://doi.org/10.1016/J.COMPEDU.2017.01.006

Hoofman, J., \& Secord, E. (2021). The Effect of COVID-19 on Education. Pediatric Clinics of North America. https://doi.org/10.1016/J.PCL.2021.05.009

Instefjord, E. J., \& Munthe, E. (2017). Educating digitally competent teachers: A study of integration of professional digital competence in teacher education. Teaching and Teacher Education, 67, 37-45. https://doi.org/10.1016/j.tate.2017.05.016

Limani, Y., Hajrizi, E., Stapleton, L., \& Retkoceri, M. (2019). Digital transformation readiness in higher education institutions (hei):the case of kosovo. IFAC-PapersOnLine, 52(25), 52-57. https://doi.org/10.1016/j.ifacol.2019.12.445

Maqableh, M., \& Alia, M. (2021). Evaluation online learning of undergraduate students under lockdown amidst COVID-19 Pandemic: The online learning experience and students' satisfaction. Children and Youth Services Review, 128, 106160. https://doi.org/10.1016/J.CHILDYOUTH.2021.106160

Moghavvemi, S., Sulaiman, A., Jaafar, N. I., \& Kasem, N. (2018). Social media as a complementary learning tool for teaching and learning: The case of youtube. The International Journal of Management Education, 16(1), 37-42. https://doi.org/10.1016/J.IJME.2017.12.001

Nasiri, M., Ukko, J., Saunila, M., \& Rantala, T. (2020). Managing the digital supply chain: The role of smart technologies. Technovation, 96-97, 102121. https://doi.org/10.1016/j.technovation.2020.102121

Pal, D., \& Vanijja, V. (2020). Perceived usability evaluation of Microsoft Teams as an online learning platform during COVID-19 using system usability scale and technology acceptance model in India. Children and Youth Services Review, 119, 105535. https://doi.org/10.1016/J.CHILDYOUTH.2020.105535

Patricia Aguilera-Hermida, A. (2020). College students' use and acceptance of emergency online learning due to COVID-19. International Journal of Educational Research Open, 1, 100011. https://doi.org/10.1016/J.IJEDRO.2020.100011

Rajhans, V., Memon, U., Patil, V., \& Goyal, A. (2020). Impact of COVID-19 on academic activities and way forward in Indian Optometry. Journal of Optometry, 13(4), 216-226. https://doi.org/10.1016/J.OPTOM.2020.06.002

Sailer, M., Murböck, J., \& Fischer, F. (2021). Digital learning in schools: What does it take beyond digital technology? Teaching and Teacher Education, 103, 103346. https://doi.org/10.1016/j.tate.2021.103346

Shah, S. S., Shah, A. A., Memon, F., Kemal, A. A., \& Soomro, A. (2021). Online learning during the COVID-19 pandemic: Applying the self-determination theory in the 'new normal.' Revista de Psicodidáctica (English Ed.), 26(2), 168-177. https://doi.org/10.1016/J.PSICOE.2020.12.003

Tang, Y. M., Chen, P. C., Law, K. M. Y., Wu, C. H., Lau, Y. yip, Guan, J., He, D., \& Ho, G. T. S. (2021). Comparative analysis of Student's live online learning readiness during the coronavirus (COVID-19) pandemic in the higher education sector. Computers \& Education, 168, 104211. https://doi.org/10.1016/J.COMPEDU.2021.104211

Taylor, K., Nettleton, S., \& Harding, G. (2004). Sociology for Pharmacists Second Edition. Taylor \& Francis.

Toto, G. A., \& Limone, P. (2021). From resistance to digital technologies in the context of the reaction to distance learning in the school context during COVID-19. Education Sciences, 11(4). https://doi.org/10.3390/EDUCSCI11040163

Vandenberg, S., \& Magnuson, M. (2021). A comparison of student and faculty attitudes on the use of Zoom, a video conferencing platform: A mixed-methods study. Nurse Education in Practice, 54, 103138. https://doi.org/10.1016/J.NEPR.2021.103138 
Warfvinge, P., Löfgreen, J., Andersson, K., Roxå, T., \& Åkerman, C. (2021). The rapid transition from campus to online teaching - how are students' perception of learning experiences affected? European Journal of Engineering Education, 1-19. https://doi.org/10.1080/03043797.2021.1942794

Wong, J., Baars, M., He, M., de Koning, B. B., \& Paas, F. (2021). Facilitating goal setting and planning to enhance online self-regulation of learning. Computers in Human Behavior, 124, 106913. https://doi.org/10.1016/J.CHB.2021.106913

Yildiz, E. P. (2020). Opinions of academicians on digital literacy: A phenomenology study. Cypriot Journal of Educational Sciences, 15(3), 469-478. https://doi.org/10.18844/cjes.v15i3.4913

Zain, S. (2021). Digital transformation trends in education. In Future Directions in Digital Information (pp. 223-234). Elsevier. https://doi.org/10.1016/b978-0-12-822144-0.00036-7

Zhao, Y., Pinto Llorente, A. M., \& Sánchez Gómez, M. C. (2021). Digital competence in higher education research: A systematic literature review. Computers and Education, 168, 104212. https://doi.org/10.1016/j.compedu.2021.104212 